\title{
PERSEPSI PEMANGKU KEPENTINGAN DALAM PENGELOLAAN WISATA BAHARI DI KEPULAUAN KAPOPOSAN KABUPATEN PANGKEP
}

\author{
(Stakeholders Perceptions on Marine Tourism Management \\ of Kapoposan Islands in Pangkep Regency)
}

Krishna Samudra ${ }^{1}$, Mulyono S. Baskoro², Sugeng H. Wisudo ${ }^{2}$, Budhi H. Iskandar ${ }^{2}$

\begin{abstract}
Kapoposan islands in Pangkep Regency consist of six small islands named are Kapoposan, Gondongbali, Papandangan, Suranti, Tambakulu and Pamanggangan. Those six islands with the area, will be developing on marine tourism activities. The primary data was collected by survey, deep interview and focus group discussion activities, which being process with Analytical Hierarchy Process (AHP) with helping by expert choice. Based on AHP result, the priority of stakeholders perceptions on marine tourism management of Kapoposan Islands in Pangkep Regency as like this follow: the Central Goverment, the Regency Goverment, the private sector, and non bureaucracy institusion.
\end{abstract}

Keywords : stakeholders perceptions, small islands, marine tourism, kapoposan

\begin{abstract}
ABSTRAK
Kepulauan Kapoposan di Kabupaten Pangkep terdiri dari enam pulau kecil yaitu Pulau Kapoposan, Gondongbali, Papandangan, Suranti , Tambakulu, dan Pamanggangan. Berdasarkan Keputusan Bupati Pangkajene dan Kepulauan Nomor 180 Tahun 2009 tentang Penetapan Kawasan Konservasi Laut Daerah Kabupaten Pangkep, keenam pulau kecil di kawasan Kepulauan Kapoposan pengembangannya diarahkan bagi kegiatan wisata bahari yang berkelanjutan. Pengambilan data dilakukan melalui survei, wawancara dengan key person, dan wawancara kelompok terfokus, yang dilanjutkan dengan pengolahan data menggunakan Analytical Hierarchy Process (AHP) dengan bantuan expert choice. Persepsi pemangku kepentingan terhadap pengelolaan wisata bahari di kawasan Kepulauan Kapoposan berdasarkan AHP, sesuai urutan prioritas pemangku kepentingan yang paling memiliki peran adalah Pemerintah Pusat, Pemerintah Daerah, dunia usaha dan institusi non birokrasi.
\end{abstract}

Kata kunci : pemangku kepentingan, wisata bahari, pulau-pulau kecil, kapoposan

\section{PENDAHULUAN}

Kawasan Kepulauan Kapoposan memiliki enam pulau kecil, yaitu Pulau Kapoposan (berpenduduk), Pulau Gondongbali (berpenduduk), Pulau Papandangan (berpenduduk), Pulau Suranti (tidak berpenduduk), Pulau Tambakulu (tidak berpenduduk), dan Pulau Pamanggangan (tidak berpenduduk) dengan wilayah administrasi seperti disampaikan pada Tabel 1 .

Berdasarkan Keputusan Bupati Pangkajene dan Kepulauan Nomor 180 Tahun 2009 tentang Penetapan Kawasan Konservasi Laut Daerah Kabupaten Pangkep, keenam pulau kecil di kawasan Kepulauan Kapoposan dimaksud pengembangannya diarahkan bagi kegiatan kegiatan wisata bahari, yaitu kegiatan yang menjadi bagian dari wisata lingkungan atau ekowisata dengan kegiatan berdasarkan daya tarik kelautan, dengan daya tarik mencakup kegiatan yang beragam, antara lain perjalanan dengan moda laut, pengamatan kekayaan alam laut dan melakukan kegiatan di laut seperti memancing, selam, selancar, dayung maupun menyaksikan upacara adat. Prinsip-prinsip dasar pengembangan pariwisata di pulau-pulau kecil meliputi: (1) prinsip keseimbangan antara pembangunan ekonomi, sosial, budaya dan konservasi; (2) prinsip melibatkan partisipasi masyarakat lokal; (3) prinsip konservasi; (4) prinsip keterpaduan dengan memperhatikan ekosistem pulau luar dan disinerjikan dengan pembangunan berbagai sektor; dan (4) prinsip penegakan hukum sesuai dengan aturan-aturan hukum yang ada dalam menjamin kepastian hukum. Berdasarkan kondisi tersebut, dibutuhkan suatu analisis bagaimana pendapat para pemangku kepentingan, mengingat pengembangan

\footnotetext{
${ }^{I}$ Staf Kementerian Kelautan dan Perikanan

${ }^{2}$ Staf Pengajar Departemen Pemanfaatan Sumberdaya Perikanan, FPIK-IPB
} 
kegiatan wisata bahari di kawasan Kepulauan Kapoposan meskipun kegiatannya berada di daerah, namun tetap tidak dapat terlepas dari kebijakan Pemerintah Pusat, dunia usaha (investasi), institusi non birokrasi (seperti perguruan tinggi, LSM, dan tokoh masyarakat/tokoh agama lokal).

Beberapa penelitian mengenai pulaupulau kecil yang telah dilakukan antara lain adalah keberlanjutan pembangunan pulau kecil dengan studi kasus Pulau Panggang dan Pulau Pari, Kepulauan Seribu-DKI Jakarta oleh Setyo Budi Susilo (2003), yang bertitik berat pada analisis ekonomi-ekologis terhadap Pulau Panggang dan Pulau
Pari yang berada di dua kawasan yang berbeda. Penelitian lain adalah analisis kebijakan pemanfaatan pulau-pulau kecil perbatasan dengan kasus Pulau Sebatik, Kabupaten Nunukan-Kalimantan Timur oleh Mustafa Abubakar (2004), yang bertitik berat pada fungsi strategis pertahanan keamanan di Pulau Sebatik sebagai pulau kecil yang berada di wilayah perbatasan antara Indonesia-Malaysia. Namun penelitian terdahulu dimaksud belum menyinggung bagaimana suatu pola pengelolaan gugusan pulau-pulau kecil yang berada dalam satu kawasan konservasi melalui kegiatan wisata bahari.

Tabel 1. Wilayah Administrasi Kawasan Kepulauan Kapoposan

\begin{tabular}{|c|c|c|c|c|c|}
\hline Nama Desa & Nama Pulau & $\begin{array}{c}\text { Luas Daratan } \\
\text { (ha) }\end{array}$ & $\begin{array}{c}\text { Luas } \\
\text { Terumbu } \\
\text { Karang (ha) }\end{array}$ & $\begin{array}{c}\text { Luas Total } \\
\text { (ha) }\end{array}$ & $\begin{array}{l}\text { Berpenduduk/ } \\
\text { Kosong (Jiwa) }\end{array}$ \\
\hline $\begin{array}{l}\text { Mattiro } \\
\text { Ujung }\end{array}$ & $\begin{array}{ll}\text { - } & \text { Kapoposan } \\
\text { - } & \text { Papandangan }\end{array}$ & $\begin{array}{lc}- & 42,05 \\
- & 6,69\end{array}$ & $\begin{array}{ll}- & 405,7 \\
- & 61,72\end{array}$ & $\begin{array}{l}-447,75 \\
-68,41\end{array}$ & $\begin{array}{l}-484 \\
-853\end{array}$ \\
\hline $\begin{array}{l}\text { Mattiro } \\
\text { Mattae }\end{array}$ & $\begin{array}{ll}\text { - } & \text { Gondongbali } \\
\text { - } & \text { Suranti } \\
\text { - } & \text { Tambakulu } \\
\text { - } & \text { Pamanggangan }\end{array}$ & $\begin{array}{ll}- & 5,28 \\
- & 2,01 \\
- & 1,81 \\
- & 1,74\end{array}$ & $\begin{array}{l}-\quad 54,92 \\
-\quad 94,72 \\
-\quad 78,77 \\
-\quad 0,157\end{array}$ & $\begin{array}{ll}- & 60,21 \\
- & 96,74 \\
- & 10,19 \\
- & 80,52\end{array}$ & $\begin{array}{l}\text { - } 1.171 \\
\text { - Kosong } \\
\text { - Kosong } \\
\text { - Kosong }\end{array}$ \\
\hline
\end{tabular}

Sumber: Dinas Kelautan dan Perikanan Kabupaten Pangkep, 2007

\section{METODE PENELITIAN}

Penelitian dilakukan pada bulan Juni 2009 sampai dengan bulan Februari 2010 di kawasan Kepulauan Kapoposan, Kabupaten Pangkep, Sulawesi Selatan. Pengumpulan data sekunder dari instansi pemerintah (baik di pusat maupun di daerah), buku-buku pustaka, jurnal, dan sumber informasi lainnya. Penelitian bersifat deskriptif dengan menggunakan teknik survei, wawancara semi terstruktur secara purposive sampling berdasarkan panduan daftar pertanyaan yang fleksibel terhadap responden kunci (key person).

(1) Wawancara dengan responden kunci (key person) di tingkat pusat meliputi: Direktur Pemberdayaan Pulau-pulau Kecil DKP, Kepala Sub Direktorat Akses dan Akselerasi Investasi Pulau-pulau Kecil DKP, Kepala Sub Direktorat Identifikasi Potensi Pulau-pulau Kecil DKP, Kepala Sub Direktorat Sarana dan Prasarana Pulau-pulau Kecil DKP, Kepala Sub Direktorat Pengelolaan Ekosistem Pulau-pulau Kecil DKP, Sekretaris Jenderal Gabungan Pengusaha Wisata Bahari Seluruh Indonesia, Sekretaris
Jenderal Masyarakat Pariwisata Indonesia, Ahli Hukum Investasi, pemerhati lingkungan, dan Pembina Program Mitra Bahari Regional Sulawesi Selatan beserta mitra perguruan tinggi. Responden kunci di tingkat daerah Kabupaten Pangkep meliputi: Kepala Dinas Kelautan dan Perikanan, Kepala Bidang Pesisir dan Pulau-pulau Kecil Dinas Kelautan dan Perikanan, Kepala Bidang Bina Usaha dan Kelembagaan Dinas Kelautan dan Perikanan, Kepala Bidang Pembinaan dan Pengawasan Dinas Kelautan dan Perikanan, Kepala Bidang Perikanan Tangkap dan Budidaya Dinas Kelautan dan Perikanan, Ketua Badan Perencanaan Pembangunan Daerah, Kepala Dinas Pariwisata, Kepala Dinas Lingkungan Hidup, Kepala Kantor Perizinan Satu Atap, Kepala Badan Koordinasi Penanaman Modal Daerah, tokoh masyarakat formal/informal, lembaga swadaya setempat, pemilik alat tangkap dan kapal, serta pihak terkait lainnya.

(2) Wawancara kelompok terfokus (focus group discussion/FGD) di pusat dengan melibatkan Departemen Kela-utan dan Perikanan (DKP), Departemen Kebuda- 
yaan dan Pariwisata (Depbudpar), Departemen Lingkungan Hidup (KLH), Masyarakat Pariwisata Indonesia (MPI), Gabungan Pengusaha Wisata Bahari Seluruh Indonesia (Gahawisri), Kamar Dagang dan Industri (Kadin), WWF Indonesia, Perkumpulan Telapak, Yayasan Kehati, Pembina Program Mitra Bahari (PMB) serta mitra perguruan tinggi (wakil dari Universitas Indonesia, Institut Pertanian Bogor, Universitas Lampung, dan Universitas Hasanuddin). Sedangkan di daerah, wawancara dilakukan bersama Bupati dan Satuan Kerja Perangkat Daerah (SKPD) Kabupaten Pangkep, dengan hasil kesepakatan pengisian kuesioner dilakukan oleh: Pejabat lingkup Eselon II dan III Dinas Kelautan dan Perikanan, Badan Perencanaan Pembangunan Daerah, Dinas Pariwisata, Dinas Lingkungan Hidup, Kantor Perizinan Satu Atap, dan Badan Koordinasi Penanaman Modal Daerah (BKPMD). Untuk tokoh masyarakat Kawasan Kapoposan disepakati adalah Camat Kecamatan Liukang Tuppabiring, Kepala Desa Mattiro Ujung, Kepala Desa Mattiro Mattae, pengumpul ikan karang ekonomis (ponggawa sunu), ketua kelompok mantan pembudidaya rum-put laut, ketua karang taruna, serta guru agama/ketua pengurus mesjid di Pulau Kapoposan.

Analisis data yang dilakukan dengan menggunakan Analisis Analytical Hierarchy Process (AHP) dengan bantuan expert choice, menunjukkan bahwa level nilai inconsistency ratio yang diperoleh adalah 0,03.

\section{HASIL DAN PEMBAHASAN}

Persepsi pemangku kepentingan terhadap pengelolaan wisata bahari di kawasan Kepulauan Kapoposan seperti terlihat pada Gambar 1.

\section{Level Aktor}

Penetapan prioritas pada level aktor didasarkan pada tingkat pengaruh masingmasing aktor terhadap pengelolaan kawasan Kepulauan Kapoposan yang berkelanjutan. Berdasarkan penilaian pada level aktor, urutan prioritas aktor adalah Pemerintah Pusat $(0,649)$, Pemerintah Daerah $(0,177)$, dunia usaha $(0,107)$ dan institusi non birokrasi $(0,107)$.

Pemerintah Pusat bertindak sebagai penyusun kebijakan nasional berupa suatu perencanaan pembangunan nasional dalam rangka mewujudkan suatu kondisi kehidupan bernegara dan bermasyarakat yang lebih baik dari kondisi saat ini, dengan mendorong pertumbuhan dan berkembangnya kemampuan suatu komunitas masyarakat baik secara kualitatif maupun kuantitatif. Untuk mewujudkan tujuan dimaksud, maka Pemerintah Pusat membentuk suatu unit kerja yang mempunyai tugas khusus untuk merumuskan dan melaksanakan kebijakan serta standardisasi teknis di bidang kelautan, pesisir dan pulau-pulau kecil melalui Departemen Kelautan dan Perikanan atau DKP. Peraturan Menteri Kelautan dan Perikanan No. PER.07/-MEN/2005 tentang Organisasi dan Tata Kerja Departemen Kelautan dan Perikanan, menetapkan bahwa unit kerja yang bertugas untuk merumuskan dan melaksanakan kebijakan serta standardisasi teknis di bidang kelautan, pesisir dan pulaupulau kecil adalah Direktorat Jenderal Kelautan, Pesisir dan Pulau-pulau Kecil (Ditjen KP3K).

UU No. 32/2004 tentang Pemerintahan Daerah membawa implikasi bahwa sumberdaya pulau-pulau kecil tidak lagi bersifat terbuka, melainkan terkontrol (controlled access). Pemerintah Daerah beserta masyarakat lokal diharapkan mampu bertanggung jawab mengendalikan pengelolaan sumberdaya pulau-pulau kecil tersebut sehingga kelestarian sumberdaya terus terjaga. Desentralisasi pengelolaan sumberdaya pulau-pulau kecil merupakan langkah yang tepat sehingga patut dijadikan entry point bagi pengelolaan sumberdaya secara berkelanjutan (sustainable resources development).

Berkaitan dengan kehadiran investasi di kawasan Kepulauan Kapoposan, Pemerintah Daerah telah memiliki landasan yang kuat untuk mengimplementasikan pembangunan pulau-pulau kecil secara terpadu mulai dari aspek perencanaan, pemanfaatan, pengawasan dan pengendalian sumberdaya pulau-pulau kecil dalam upaya mendorong investasi bagi pengelolaan pulau-pulau kecil secara berkelanjutan. Sebagai pemegang izin prinsip kerjasama dengan dunia usaha, Pemerintah Daerah selayaknya dapat melakukan berbagai upaya seperti penyertaan modal daerah, menyusun prosedur atau mekanisme perizinan investasi yang transparan, tidak berbelit-belit dan akuntable, serta meningkatkan pelayanan publik berupa praktik birokrasi yang unggul (excellent practices). 
Hirarki

Fokus

PENGELOLAAN WISATA BAHARI DI KAWASAN KEPULAUAN

Aktor

Kriteri

ord

Sub

Kriteria

Alternatif

Alternatif 1:

Kegiatan wisata

bahari pulau-

pulau kecil di

kawasan

Kepulauan

Kapoposan

dikembangkan

bersama kegiatan

budidaya laut

$(0,179)$

\section{KAPOPOSAN YANG BERKELANJUTAN}

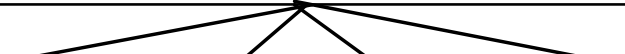

BIROKRASI

$(0,107)$ 
terserapnya tenaga masyarakat lokal dan pulau-pulau kecil sekitarnya sebagai pemandu wisata (guide), nahkoda kapal, juru masak, cleaning service, petugas keamanan, jasa penyewaan perahu, penjualan cidera mata, jasa penyediaan bahan makanan, dan administrator kantor; (2) meningkatnya kesadaran masyarakat lokal menjaga lingkungan dan sumberdaya alam sebagai aset utama kegiatan wisata bahari, sehingga berbagai upaya pelestarian lingkungan dilakukan oleh masyarakat, serta terhindarkannya pemanfaatan sumberdaya melalui kegiatan yang destruktif (penggunaan racun dan bom); dan (3) sebagai sumber pemasukan devisa negara dan Pendapatan Asli Daerah atau PAD.

Perguruan tinggi dengan Tri Dharmanya, yaitu pendidikan dan pengajaran, penelitian, serta pengabdian pada masyarakat, menduduki peran yang penting dan strategis, khususnya dalam perkembangan ilmu pengetahuan, teknologi dan penelitianpenelitian yang dapat dipertanggungjawabkan secara ilmiah. Penelitian-penelitian berkesinambungan meliputi potensi ekonomi dari pemanfaatan sumberdaya alam yang lestari, teknologi penangkapan dan budidaya ramah lingkungan, serta penelitian atas perilaku sosial budaya masyarakat pulau-pulau kecil dalam menerima dan melaksanakan program-program pembangunan, merupakan kajian yang selayaknya diterapkan dalam mendukung pengelolaan kawasan Kepulauan Kapoposan yang berkelanjutan.

Era demokrasi telah membuka pintu bagi kiprah peran serta lembaga swadaya masyarakat (LSM) sebagai organisasi non pemerintah (non goverment organization) yang menjadi mitra pemerintah, khususnya dalam upaya pengelolaan sumberdaya dan pemberdayaan masyarakat pulau-pulau kecil di daerah. Langkah-langkah pendampingan dari LSM dalam pengelolaan kawasan Kepulauan Kapoposan di lapangan, diharapkan dapat menjadi motivator bagi perubahan perilaku masyarakat lokal dalam pengelolaan sumberdaya pulaupulau kecil berbasis masyarakat atau community based management (CBM) dan cooperative management atau comanagement.

Kawasan Kepulauan Kapoposan seperti juga kawasan pulau-pulau kecil pada umumnya, secara kultural memiliki tokohtokoh masyarakat atau tokoh agama yang memiliki peran penting sebagai panutan atau yang diberi mandat oleh masyarakat lokal sebagai wakil masyarakat pulau-pulau kecil dalam hubungannya dengan pembangunan masyarakat. Para tokoh dimaksud (bersama-sama LSM) berperan dalam membantu mengorganisir masyarakat dalam menerima teknologi baru, pengembangan pendidikan dan pelatihan, pengembangan modal dan kredit masyarakat, perbaikan lingkungan, penetapan kawasan konservasi, pelaksanaan pemantauan dan pengawasan, perencanaan dan pengelolaan, serta perumusan kebijakan yang tidak jarang dapat mempengaruhi kebijakan pemerintah, baik pusat maupun daerah. Peran para tokoh masyarakat/tokoh agama menjadi kian kuat, tatkala kawasan Kepulauan Kapoposan diarahkan bagi pengembangan kegiatan wisata bahari, terutama dalam hal menghindari terjadinya konflik atau benturan antara budaya lokal dengan budaya asing akibat kehadiran para wisatawan.

\section{Level Kriteria}

Penetapan prioritas pada level kriteria didasarkan pada tingkat kepentingan masing-masing kriteria terhadap pengelolaan kawasan Kepulauan Kapoposan yang berkelanjutan. Berdasarkan penilaian pada level kriteria, urutan prioritas kriteria adalah Politik $(0,66)$, Ekonomi $(0,159)$, Sosial Budaya $(0,097)$ dan Lingkungan $(0,067)$.

Berdasarkan penilaian pada level kriteria, urutan prioritas kriteria pertama adalah politik, lalu diikuti oleh ekonomi, sosial budaya dan lingkungan. Kondisi ini tidak dapat terlepas dari kondisi masa ini, dimana peran politik mengambil peran yang sangat strategis dalam suatu keberhasilan ataupun kemunduran suatu bangsa, serta mempengaruhi para penguasa ataupun pemimpin nasional dalam mewujudkan kejayaan bangsa sesuai pada zamannya masing-masing. Menurut Syafiie (2009), politik pada dasarnya memiliki ruang lingkup negara sebagai lembaga politik yang mem-pengaruhi hidup masyarakat, sebagai kebijaksanaan, kekuatan, serta kekuasaan pemerintah yang membuat negara dalam keadaan bergerak. Peran pemimpin nasional yang secara politik memiliki kekuasaan penuh dalam memimpin dan membawa bangsa ini mencapai tujuan, tidak pelak menjadikannya sebagai tokoh sentral dalam pembangunan diberbagai bidang, termasuk pembangunan pulau-pulau kecil.

Keputusan politik pemimpin negara yang berpihak pada sektor kelautan, berdampak sangat signifikan terhadap per- 
tumbuhan ekonomi. DKP (2007), menyatakan bahwa dalam rentang sewindu berdirinya Departemen Kelautan dan Perikanan, sektor kelautan dan perikanan mengalami pertumbuhan ekonomi yang pesat, yang ditunjukkan dengan kenaikan sekitar 15,5\% Produk Domestik Bruto (PDB) sub sektor perikanan pada periode 20002006. Kontribusi subsektor perikanan terhadap sektor pertanian setiap tahun meningkat dengan rata-rata sebesar 3\% (bahkan pada 2006 kontribusi tersebut hampir mencapai 17\%), sedangkan jika dihitung dengan kontribusi dari kegiatan pengolahan produk perikanan, maka kontribusi subsektor perikanan terhadap PDB nasional mencapai sekitar 2,4\%, di luar kegiatan wisata bahari.

Dinamika global dalam persaingan ekonomi membutuhkan ketahanan sosial budaya masyarakat pulau-pulau kecil, khususnya masyarakat di kawasan Kepulauan Kapoposan yang pada umumnya berprofesi sebagai nelayan, namun memiliki kearifan lokal dalam pemanfaatan sumberdaya dan pelestarian lingkungan. Retraubun (2003), menyebutkan bahwa salah satu solusi yang mungkin dapat diterapkan dan diterima masyarakat pulaupulau kecil adalah dilaksanakannya pelimpahan wewenang pengelolaan (decentralization) sumberdaya pulau-pulau kecil kepada masyarakat komunal pulau atau kelembagaan lokal, yang lebih mengetahui teknis dan mekanisme pemanfatan sumberdaya secara berkelanjutan yang merupakan warisan dari nenek moyangnya, sehingga dapat memenuhi kebutuhan pangan, sandang, papan, kesehatan, pendidikan, lapangan kerja, terhindar dari resiko-resiko kerusakan lingkungan, serta tetap lestarinya aset pendukung kehidupan menuju masyarakat pulau yang maju dan mandiri.

\section{Level Subkriteria}

Penetapan prioritas pada level subkriteria didasarkan pada tingkat pengaruh masing-masing subkriteria terhadap pengelolaan kawasan Kepulauan Kapoposan yang berkelanjutan. Berdasarkan penilaian pada level subkriteria, urutan prioritas subkriteria adalah wawasan nusantara $(0,0763)$, kepemimpinan nasional dan daerah $(0,0470)$, kebijakan berbasis kelautan $(0,0395)$, infrastruktur dasar $(0,0-270)$, pertambahan penduduk/demografi $(0,0133)$, konservasi $(0,0098)$, proporsi anggaran yang berimbang $(0,0078)$, pertumbuhan ekonomi $(0,0065)$, penyerapan tenaga kerja $(0,0040)$, peningkatan pendapatan masyarakat $(0,0038)$, kesadaran lingkungan $(0,0035)$, kearifan lokal $(0,0034)$, pemanfaatan berkelanjutan $(0,0029)$, peningkatan PAD $(0,0024)$, tata ruang dan zonasi $(0,0017)$, dan pemanfaatan terpadu $(0,0011)$.

Paradigma pembangunan land base oriented yang dilaksanakan selama ini telah menyebabkan sumberdaya pulau-pulau kecil terabaikan. Konsep pembangunan kontinental masa lalu dengan paradigma pertumbuhan yang seragam di seluruh Indonesia telah mengasingkan sumberdaya pulau-pulau kecil dari pengelolaan yang bijak, bahkan pemanfaatannya justru dilakukan dengan bertitik tolak pada eksploitasi sumberdaya secara besar-besaran, tanpa mengindahkan kelestarian lingkungan sehingga sumber daya pulau-pulau kecil mengalami over exploited. Kondisi ini menyebabkan wawasan nusantara menjadi sub kriteria yang menjadi prioritas utama. Wawasan nusantara sesungguhnya adalah perwujudan yang nyata sebagai ikrar the founding fathers dalam melihat, menerima dan mensyukuri kondisi obyektif Bangsa Indonesia sebagai negara kepulauan terbesar di dunia yang mengartikan tanah air Indonesia sebagai satu kesatuan dalam politik, ekonomi, sosial, budaya dan pertahanan keamanan (Retraubun, 2007).

Wawasan Nusantara selayaknya menjadi modal utama bangkitnya kesadaran pemimpin nasional dan daerah untuk menggunakan paradigma baru, yaitu paradigma archipelagic state oriented sesuai kondisi obyektif bangsa sebagai negara kepulauan terbesar di dunia. Kesadaran pemimpin nasional dan daerah akan kondisi obyektif bangsa akan mempengaruhi isi berbagai kebijakan yang memang seharusnya berbasis kelautan, khususnya bagi kebijakan-kebijakan kelautan dan perikanan pada umumnya, khususnya pengelolaan pulau-pulau kecil, termasuk di dalamnya kawasan Kepulauan Kapoposan.

Kebijakan pemerintah (baik pusat maupun daerah) yang berbasis kelautan adalah suatu hal yang mutlak bagi Indonesia sebagai negara kepulauan, sehingga pembangunan dapat diarahkan dengan proporsi anggaran yang berimbang khu-susnya dalam penyediaan infrastruktur dasar yang dapat membuka peluang masyarakat untuk meningkatkan pertumbuhan ekonomi kawasan. Pengelolaan kawasan Kepulauan Kapoposan yang terdiri dari enam pulau kecil beserta perairannya, segala aktivitas di dalamnya seyogyanya berbasis konservasi. 
Konservasi sebagai upaya menabung sumberdaya bagi masa depan diharapkan dapat semakin menumbuhkan kesadaran lingkungan masyarakat dan meningkatkan kualitas kearifan lokal yang ada dalam pemanfaatan sumberdaya berkelanjutan dan terpadu. Hal ini menjadi semakin penting dengan telah disusunnya tata ruang dan zonasi kawasan Kepulauan Kapoposan yang mendorong bagi terbukanya peluang investasi wisata bahari, yang pada akhirnya selain dapat menyerap tenaga kerja akibat per-tumbuhan penduduk, meningkatkan pendapatan masyarakat, serta merupakan sumber peningkatan Pendapatan Asli Daerah atau PAD.

\section{Alternatif}

Penetapan prioritas pada level alternatif didasarkan pada alternatif terbaik yang ingin dicapai dalam pengelolaan kawasan Kepulauan Kapoposan yang berkelanjutan. Berdasarkan penilaian, urutan prioritas alternatif pertama adalah alternatif 4, yaitu kegiatan wisata bahari pulau-pulau kecil di kawasan Kepulauan Kapoposan berbasis konservasi $(0,475)$; kedua adalah alternatif 3 , yaitu kegiatan wisata bahari pulau-pulau kecil di kawasan Kepulauan Kapoposan dikembangkan bersama perikanan tangkap $(0,288)$; ketiga adalah alternatif 2, yaitu kegiatan wisata bahari pulaupulau kecil di kawasan Kepulauan Kapoposan dikembangkan bersama kegiatan budidaya laut dan perikanan tangkap $(0,174)$; dan keempat adalah alternatif 1 , yaitu kegiatan wisata bahari pulau-pulau kecil di kawasan Kepulauan Kapoposan dikembangkan bersama kegiatan budidaya laut $(0,063)$.

Wisata bahari berbasis konservasi merupakan kegiatan yang sesuai dengan pri-nsip ekowisata, yang menyatakan bahwa ekowisata adalah penyelenggaraan pariwisata dikawasan lindung dan kawasan alam binaan dengan berbasis konservasi, melibatkan partisipasi masyarakat secara aktif, serta bermuatan pendidikan dan pembelajaran. Indonesia berpeluang menjadi salah satu tujuan wisata bahari di pulaupulau kecil terbesar di dunia, dengan basis Marine Ecotourism, yaitu bagian dari wisata lingkungan atau ekowisata yang kegiatannya berdasarkan daya tarik kelautan, mengingat wilayah Indonesia yang merupakan bagian dari Asia Tenggara memiliki potensi pariwisata bahari yang lebih baik dibandingkan dengan kawasan Mediterranian dan Carribean (Kementerian Kebudayaan dan Pariwisata, 2004).

Berdasarkan hasil uji sensitivitas terhadap keempat alternatif pengelolaan gugusan pulau-pulau kecil di Kawasan Kapoposan (Tabel 2), alternatif kegiatan wisata bahari di gugusan pulau-pulau kecil di Kawasan Kapoposan yang dikembangkan berbasis konservasi tetap stabil, meskipun salah satu aktor (baik Pemerintah Pusat, Pemerintah Daerah, dunia usaha maupun institusi non birokrasi) merupakan aktor yang memiliki peran terbesar ataupun terkecil.

Tabel 2. Hasil uji sensitivitas terhadap alternatif pengelolaan

\begin{tabular}{|l|l|c|c|c|}
\hline \multirow{2}{*}{ No. } & \multirow{2}{*}{ Intervensi Aktor } & \multirow{2}{*}{ Rasio Kepentingan } & \multicolumn{2}{|c|}{ Range Sensitivitas } \\
\cline { 3 - 4 } & & & Range Sensitif & Range Stabil \\
\hline 1 & Pemerintah Pusat (PEMP) & 0,649 & Tidak Ada & $0-100 \%$ \\
\hline 2 & Pemerintah Daerah (PEMD) & 0,177 & Tidak Ada & $0-100 \%$ \\
\hline 3 & Dunia Usaha (DUHA) & 0,107 & Tidak Ada & $0-100 \%$ \\
\hline 4 & Institusi Non Birokrasi (INOB) & 0,107 & Tidak Ada & $0-100 \%$ \\
\hline
\end{tabular}

Sumber: Berdasarkan Data Olahan (2009)

Menurut DKP (2006), nilai ekonomi ekoturisme dari kegiatan wisata bahari di pulau-pulau kecil meliputi beberapa hal berikut:

1) Keunggulan komparatif alam Indonesia (khususnya berupa sebaran terumbu karang di pesisir dan pulau-pulau kecil) merupakan dasar wisata bahari berbasis ekowisata yang memberikan nilai ekonomi sangat besar bagi pembangunan daerah dan nasional;
2) Pengembangan dan pembangunan wisata bahari dengan adanya kunjungan wisatawan memiliki efek ganda atau multiplier effect meliputi:

(1) penyerapan tenaga kerja lokal guna menekan pengangguran;

(2) pelestarian lingkungan perairan yang mendukung kelimpahan sumberdaya ikan bagi perikanan tangkap dan terjaganya kualitas perairan 
dalam mendukung kegiatan budidaya

(3) memacu pertumbuhan ekonomi sektor perikanan lokal seperti berdirinya industri perikanan rumah tangga masyarakat lokal meliputi penangkapan, pengolahan dan pemasaran hasil perikanan bagi wisatawan;

(4) memacu pertumbuhan ekonomi melalui perdagangan/niaga berupa pembelian barang primer (seperti 9 bahan pokok), sekunder (seperti hasil bumi dan kerajinan tangan), dan tersier (seperti jasa atau service pemandu wisata serta penyewaan alat-alat rekreasi seperti perahu, alat selam dan lainnya);

(5) pembangunan fasilitas kenyamanan seperti resort dan restoran (oleh investor), ataupun pemanfaatan home stay dan warung makan milik masyarakat setempat;

(6) pembukaan jalur transportasi baik udara, laut maupun darat yang membuka keterisolasian dari lokasi pulau kecil tujuan wisata ke pulaupulau kecil di sekitarnya;

(7) masuknya devisa melalui wisatawan asing dan kapal-kapal pesiar yang melintas dan singgah di Indonesia.

Wisata bahari berbasis konservasi di kawasan Kepulauan Kapoposan menjadi alternatif prioritas utama pengembangan karena diyakini oleh masyarakat lokal dan para pemangku kepentingan, bahwa aktivitas dimaksud memiliki efek ganda (multiplier effect) bagi peningkatan kesejahteraan masyarakat, pelestarian lingkungan, serta merupakan aktivitas yang memenuhi segenap kriteria pembangunan berkelanjutan, yaitu bahwa pengelolaan pulau-pulau kecil harus memenuhi segenap kriteria secara ekonomi efisien dan optimal (economically sound), secara sosial-budaya berkeadilan dan dapat diterima (socio-culturally acepted and just), dan secara ekologis tidak melampaui daya dukung lingkungan (enviromentally friendly) (Retraubun, 2003).

DKP (2004) menyebutkan bahwa kegiatan wisata bahari berbasis konservasi memiliki kepedulian-kepedulian, tanggung jawab dan komitmen terhadap pelestarian alam dan pemberdayaan masyarakat karena mengikuti kaidah-kaidah ekologis, ekonomi, partisipasi masyarakat, dan edukatif meliputi:
1) memperhatikan kualitas daya dukung lingkungan daerah tujuan wisata bahari melalui pemintakatan (zonasi).

2) mengelola dan menciptakan kegiatan wisata yang berdampak negatif rendah dan ramah lingkungan.

3) menyisihkan hasil keuntungan untuk kegiatan pelestarian lingkungan dan peningkatan sumberdaya manusia setempat.

4) menjaga kualitas daerah tujuan wisata bahari melalui pengelolaan penunjang, sarana dan fasilitas.

5) meningkatkan kesadaran dan apresiasi para pelaku dan pengunjung terhadap lingkungan alam dan budaya.

6) membuka kesempatan kepada masyarakat setempat untuk berusaha dan menjadi pelaku-pelaku ekonomi kegiatan wisata bahari.

7) memberdayakan masyarakat dalam upaya peningkatan usaha wisata bahari untuk kesejahteraan penduduk setempat.

8) mengoptimalkan keunikan dan kekhasan daerah sebagai daya tarik wisata.

9) memanfaatkan dan mengoptimalkan pengetahuan tradisional yang berbasis pelestarian alam dan budaya serta nilainilai yang dikandung dalam kehidupan masyarakat sehari-hari sebagai nilai tambah.

Berdasarkan kondisi tersebut, pengembangan sektor wisata bahari berbasis konservasi di kawasan Kepulauan Kapoposan dapat menjadi harapan sebagai salah satu sektor yang diandalkan dalam menopang pembangunan ekonomi daerah dan nasional. Kepmenbudpar (2004) menyatakan, bahwa ekoturisme kegiatan wisata bahari (marine tourism) dapat menjadi program utama dalam: (1) memulihkan kerusakan sumberdaya laut, pesisir dan pulau-pulau kecil; (2) mengembalikan peranan masyarakat untuk ikut serta dalam menjaga kelestarian lingkungan; serta (3) berperan dalam menyumbangkan devisa bagi negara dan bagi peningkatan pendapatan asli daerah atau PAD.

\section{KESIMPULAN}

(1) Persepsi pemangku kepentingan terhadap pengembangan wisata bahari di Kawasan Kepulauan Kapoposan sesuai urutan prioritas, maka aktor yang paling memberikan pengaruh adalah Pemerintah Pusat, Pemerintah Daerah, dunia usaha dan institusi non birokrasi. 
(2) Wisata bahari diharapkan menjadi aktivitas yang memberikan dampak ganda (multiplier effect) berupa peningkatan pendapatan masyarakat, pendapatan asli daerah, dan devisa negara.

(3) Wisata bahari merupakan aktivitas yang dapat mendukung pemulihan sumberdaya pesisir dan pulau-pulau kecil.

\section{DAFTAR PUSTAKA}

Departemen Kelautan dan Perikanan. 2007. Sewindu Departemen Kelautan dan Perikanan: Mengawali Pembangunan Negara Kepulauan. Jakarta. $90 \mathrm{hlm}$.

2006. Laporan Akhir Model Pengembangan dan Valuasi Ekonomi Kawasan Wisata Bahari di Pulaupulau Kecil. Jakarta. 209 hlm. Kecil. ISBN $59 \mathrm{hlm}$.

Dinas Perikanan dan Kelautan Kabupaten Pangkajene Kepulauan. 2007. Profil Pulau-pulau Kecil Kabupaten Pangkajene Kepulauan. Pangkep. 170 hlm.

Keputusan Menteri Kebudayaan dan Pariwisata Nomor KM.67/UM.001/ MKP/2004 tentang Pedoman Umum Pengembangan Pariwisata di Pulaupulau Kecil. 2004. Kementerian Ke- budayaan dan Pariwisata. Jakarta. 44 hlm.

Peraturan Menteri Kelautan dan Perikanan RI Nomor PER.07/MEN/2005 tentang Organisasi dan Tata Kerja Departemen Kelautan dan Perikanan. Jakarta. 165 hlm.

Retraubun, A.S.W. 2007. Wujud Pemberdayaan Pulau-pulau Kecil dalam Peningkatan Wawasan Nusantara. Makalah disampaikan pada Acara Hari Nusantara Ke-8. Jakarta, 13 Desember 2007. $23 \mathrm{hlm}$.

2003. Kebijakan dan Strategi Pemberdayaan Pulau-pulau Kecil. Makalah disampaikan Rapat Koordinasi Penanganan Terpadu Program Pembangunan. Jakarta, 17-18 Desember 2003. $31 \mathrm{hlm}$.

Saaty TL. 1993. Pengambilan Keputusan Bagi Para Pemimpin, Proses Hierarki Analitik untuk Pengambilan Keputusan dalam situasi yang komplek. Seri Manajemen No. 134/1993. Terjemahan Sapta BU. Jakarta : Pustaka Binaman Pres-sindo, Jakarta. hlm 9-20 .

Syafiie, I.K. 2009. Pengantar Ilmu Politik. ISBN 978-979-19561-7-8. Pustaka Reka Cipta. Bandung. 357 hlm. 